elicited again in some individuals and also increased in some cultural environments.

The propensity to make a conversion - or to retain it - could at least be partly determined by a certain style of mother-child relationship. Recent advances in our knowledge of development in infancy may throw light on the origins of the conversion phenomenon. For instance, the concept of 'affect attunement', proposed by Stern (1985), can help us understand how the conversion response could be elicited through a certain kind of mother-child interaction. Here, any kind of initiative by the baby would be interpreted by the mother as being a bodily need, and she would answer in a highly aroused way. The child would then have to maintain a high level of physical excitation to keep in touch with his mother and to keep a sense of shared experience.

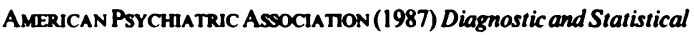
Manual of Mental Disorders (3rd edn, revised) (DSM-III-R). Washington, DC: APA.

FreUd, A. (1926) An hysterical symptom in a child of two years and three months. International Journal of Psychoanalysis, 7, 227-240.

GOODYER, I. (1981) Hysterical conversion reactions in childhood. Journal of Child Psychology and Psychiatry and Allied Disciplines, 22, 179-188.

STERN, D. N. (1985) The Interpersonal World of the Infant. New York: Basic Books.

TERRIEN, F. (1897) Hystérie infantile en Vendée. Revue Neurologique, 4(19), 299-320.

Institut de Puériculture de Paris

ANTOINE GuEDENEY 26, Bd Brune, 75014, Paris, France

\section{Folate and depression}

SIR: The folate depression debate continues with attention currently focusing on the efficiency of folate supplementation as an adjustment to standard regimens in the management of depression (Anderson et al, Journal, January 1992, 160, 130). However, the safety of such practices should also be examined as studies have shown that increased intake of folate can interfere with seizure control in epilepsy (Strauss \& Bernstein, 1974), while Reynolds (1991) suggested that excess folate intake in a pregnant woman could harm the developing nervous system of the foetus. Nonetheless, low folate levels have been found in some patients with depression. However, the results which are usually expressed as percentages do not make full use of the data for the whole group; indeed the values have varied considerably in different studies, for example $10 \%$ (Hallstrom, 1969 ) and $30 \%$ (Carney, 1967). The use of confidence intervals would give more accurate results.
We measured red blood cell folate levels in patients admitted to an acute psychiatric ward with unipolar and bipolar depression: $17 \%$ of the former group had red cell folate levels below $200 \mathrm{mg} / \mathrm{l}$ with confidence intervals of $274.2-349.6 \mathrm{mg} / \mathrm{l}$; while in the latter group the figures were $9 \%$ and $233.5-309.5 \mathrm{mg} / \mathrm{l}$. The percentage figures are not as great as in other studies but the confidence intervals were at the lower end of normal. This may suggest that low red blood cell folate levels may be an early marker of the onset of depression in some patients, and may even prove to be a sensitive marker of depression control. Measurement of red cell folate levels may have an important role to play in the clinical assessment of patients with depression.

We would therefore recommend that while investigation continues into the efficacy of folate supplementation, thought should be given to folate measurement being a part of the clinical assessment of the depressed patient.

Carney, M. W. P. (1967) Serum folate levels in 423 psychiatric patients. British Medical Journal, 4, 512-516.

HALLSTROM, T. (1969) Serum $B_{12}$ and folate concentration in mental patients. Acta Psychiatrica Scandinavica, 49, 19-36.

REYNoLDS, E. H. (1991) Folic acid to prevent neural tube defects. Lancet, 338, 505-506.

Strauss, R. G. \& Bernstein, R. (1974) Folic acid and dilantin antagonism in pregnancy. Obstetrics and Gynaecology. 44, 345-348.

Coolock Health Centre

Brian McLaughlin

Dublin 5

St Ita's Hospital

Portrane

Co. Dublin

ANNE MCMAHON

\section{Outdated ECT machines}

SIR: Dr Pippard's article (Journal, May 1992, 160, 621-637) makes an important recommendation which is supported by the result of a recent audit of electroconvulsive therapy (ECT) practice at Glenside Hospital. He advises that the Ectron Duopulse Series 3 machine does not give adequate electrical stimulation and should be replaced by a more modern machine.

In 1992, we performed a retrospective audit of ECT at our hospital. The audit criterion was that of an induced fit of greater than 25 seconds following electrical stimulation. The machine in use then was an Ectron Duopulse Series 3, which had been regularly serviced by the medical physics department. The case notes of the 73 patients who had received 